\title{
26. ELEMENTAL AND ISOTOPIC ABUNDANCE OF NOBLE GASES IN FORMATION FLUIDS RECOVERED IN SITU FROM THE CHILE TRIPLE JUNCTION ${ }^{1}$
}

\author{
Marta E. Torres, ${ }^{2}$ Reinhold Bayer, ${ }^{3}$ Gisela Winckler, ${ }^{3}$ Axel Suckow, ${ }^{3}$ and Philip N. Froelich ${ }^{4}$
}

\begin{abstract}
Sedimentary pore fluids from the Chile Triple Junction were sampled in situ, and analyzed for their noble gas composition. ${ }^{3} \mathrm{He} /{ }^{4} \mathrm{He}$ and ${ }^{4} \mathrm{He} / \mathrm{Ne}$ ratios were used to evaluate the fraction of helium in the samples that originated from mantle and radiogenic sources. The results show no primordial helium in samples recovered from Sites 860 and 861 . In contrast, a primordial component is present in two samples from a depth interval in Site 863 that corresponds to a zone of tectonic discontinuity. A decrease in the concentration of dissolved $\mathrm{K}, \mathrm{Sr}, \mathrm{Mg}$, and $\mathrm{SO}_{4}$ in this interval is consistent with the presence of a fluid which has been altered by basalt-seawater reactions. These results indicate lateral fluid migration from a hydrothermal source which is probably associated with the recently subducted Chile Ridge axis.
\end{abstract}

\section{INTRODUCTION}

The isotopic composition of dissolved helium in seawater has been shown to be an excellent tracer for the study of oceanic circulation and for detecting hydrothermal plumes in the water column (Craig and Lupton, 1989; Lupton, 1983). In pore fluids and deep sea sediments it can be used to obtain insights into fluid kinematics and fluid residence times in the ocean crust (Barnes and Clarke, 1987). Helium is a chemically inert gas that is steadily produced by radioactive decay within the sediments; this radiogenic helium is enriched in ${ }^{4} \mathrm{He}$ and thus it can be used as a tracer to derive information on fluid sources and flow patterns not available through the study of the distribution of diagenetically active chemical species. Juvenile helium is degassed from the mantle with a high ${ }^{3} \mathrm{He} /{ }^{4} \mathrm{He}$ ratio; therefore helium isotope ratios also provide insights on the distribution of hydrothermally derived fluids within the sediment column. In spite of its great potential, only a very small number of helium isotope analyses have been made on pore fluids from oceanic sediments, because of the difficulties involved in collecting gas samples from sediment boreholes.

We have examined elemental abundances of noble gases in samples collected in situ from holes drilled near the Chile Triple Junction (Fig. 1). Pore fluid samples were collected from three sites $(859,860$ and 861) located on an east-west transect of the collision zone (Fig. 2) and from one site (863) located at the base of the trench slope at the point where the Chile Ridge is being subducted (Fig. 3). The subduction of this active spreading ridge beneath a continental margin brings about an active hydrogeological system characterized by a thermally and tectonically driven fluid flow. In this environment of complex tectonic interactions and associated fluid migration, the helium distribution and its isotopic composition may help evaluate not only the extent of these interactions but also provide unique clues to fluid sources and pathways. We have used ${ }^{3} \mathrm{He} /{ }^{4} \mathrm{He}$ and $\mathrm{He} / \mathrm{Ne}$ ratios to infer fluid sources in this unique geological setting and have shown that mantle volatiles can be used as indicators of flow patterns within the trench wall.

'Lewis, S.D., Behrmann, J.H., Musgrave, R.J., and Cande, S.C. (Eds.), 1995. Proc. ODP, Sci. Results, 141: College Station, TX (Ocean Drilling Program).

GEOMAR Forschungszentrum für Marine Geowissenschaften. Wischhofstrasse 1-3, D-24148 Kiel, Federal Republic of Germany.

${ }^{3}$ Institut für Umweltphysik der Universität Heidelberg, Im Neuenheimer Feld 366. D-69120 Heidelberg, Federal Republic of Germany.

${ }^{4}$ Lamont-Doherty Earth Observatory, Columbia University, Palisades, NY 10964.

\section{EXPERIMENTAL PROCEDURES}

During the Deep Sea Drilling Project, Barnes (1979) pioneered the effort to sample fluids in situ and developed tools designed to sample sedimentary pore fluids through a probe that extends ahead of the drilling bit (Fig. 4). The latest version of this tool, known as the ODP WSTP (water sampler, temperature, pressure tool), was used to collect interstitial water samples during Leg 141. It is a self contained, battery powered device adapted to an inner core barrel assembly that is deployed on the coring wire. The sample chamber and electronics are contained within the inner core barrel; only a strong probe that contains the sampler filter and temperature sensors protrudes ahead of the bit. The tool is lowered to the end of the drill string, where it locks into an assembly just above the bit. The pore fluid sample for gas analysis is collected $1 \mathrm{~m}$ below the bottom of the drill string through titanium tubing, a $6 \mathrm{~mL}$ titanium coil and into a $40 \mathrm{~mL}$ copper coil. A one-way valve is connected to the other end of the copper coil, which allows fluid to pass into a stainless steel overflow cylinder. Prior to deployment, the fluid path is back-filled with distilled water that has been previously degassed by bubbling nitrogen. The overflow cylinder is flushed with nitrogen and evacuated. The valve is activated by a timer that is set-up so the valve will open when the tool has reached the bottom of the drill-hole. When it opens, it exposes the sampling line and chamber to ambient pressure, allowing formation fluids to displace the degassed water and fill the sampling coils; the excess fluid is be collected in the overflow chamber. The tool is recovered after the sample valve is closed. When the tool is returned to the laboratory, the ends of the copper coils are hermetically sealed with pinch-off clamps before removal from the sampler, and are then stored for shore-based analysis of the dissolved noble gases. Descriptions of the tool and its operation can be found in Barnes (1988); details of the deployments conducted during Leg 141 are given in Behrmann, Lewis, Musgrave, et al. (1992).

The dissolved gases were extracted from the samples in a vacuum system using water vapor as carrier gas. The water vapor was removed from the gas phase by a cold trap held at about $-80^{\circ} \mathrm{C}$ and the dried gas was transferred to a defined volume using a Toepler pump. A $1 \%$ fraction of the extracted raw gas mixture was passed through a quadrupole mass spectrometer (Balzers, QMG-064) attached to the extraction line to obtain an estimate of the helium and neon concentrations in the samples. Defined volume splits of the remaining rare gas mixture were performed to obtain sample aliquots of a size suitable for precise measurement of helium isotopes and other gases. These sample aliquots were transferred into break-seal glass ampoules and were then flame-sealed. 


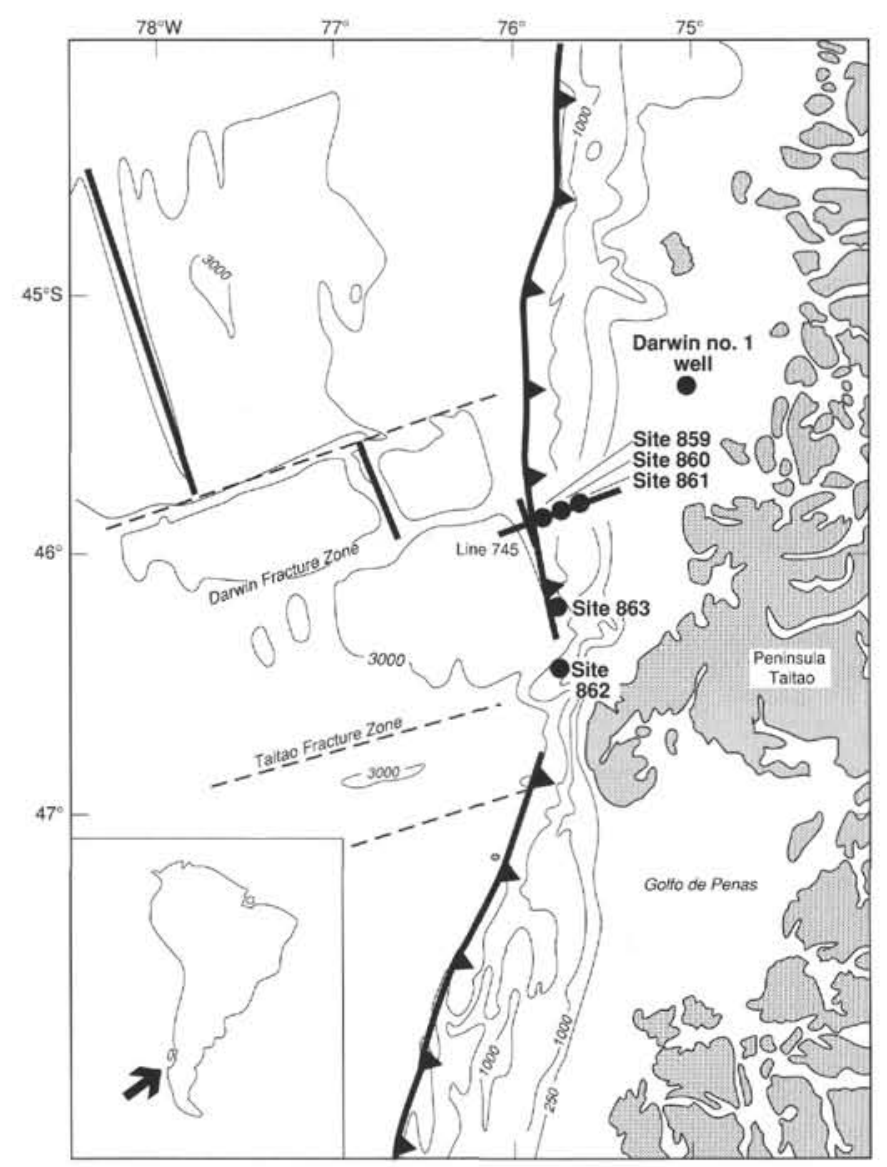

Figure 1. Map of the Chile Triple Junction region showing Leg 141 sites.

Helium isotopes were measured in a dedicated mass spectrometer (VG Instruments, MM-3000). Before analysis all the gases except helium and neon were adsorbed on a charcoal trap at liquid nitrogen temperature; helium and neon were separated by a cryogenic cold trap. ${ }^{3} \mathrm{He}$ and ${ }^{4} \mathrm{He}$ were then measured simultaneously using the peak-height method, following the procedure outlined in Bayer et al. (1989). The neon fraction was measured in a quadrupole mass spectrometer (Balzers, QMG-112). The typical precision obtained for the ${ }^{3} \mathrm{He} /{ }^{4} \mathrm{He}$ ratio ranges from approximately \pm 1 to $\pm 2 \%$. Due to the high helium concentrations, the gas fraction used for the helium isotope analysis was small compared to the total amount of gas extracted from the samples; the required volume splits significantly decreased the overall precision of the measurement of the absolute gas concentration. For this reason, we do not report the ${ }^{4} \mathrm{He}$ and neon concentrations measured with the MM-3000 mass spectrometer, but only the $\mathrm{He} / \mathrm{Ne}$ ratios, which were determined with a precision of about $\pm 3 \%$.

The gas fraction used for the analysis of the heavier noble gases was passed through a hot titanium sponge $\left(800^{\circ} \mathrm{C}\right)$ to remove chemically active gases. The remaining noble gases were then separated by adsorption on activated charcoal cooled by liquid nitrogen. This was followed by controlled heating and subsequent measurements of $\mathrm{He}$, $\mathrm{Ne}, \mathrm{Ar}, \mathrm{Kr}$, and $\mathrm{Xe}$ in a mass spectrometer (VG Instruments MM 1200). Details of this procedure are given in Rudolph et al. (1984). The overall precision of the measurements is estimated to be about $\pm 8 \%$ for helium and \pm 2 to $\pm 3 \%$ for the other gases. The data, however, may have been biased by the sampling and extraction procedures; therefore, certain values may have overall errors that are much larger than the analytical precision indicated. Specifically, some of the samples contained large amounts of methane, and thus the total pressure inside the extraction line was far above that for which the system has been optimized. The high gas content may have also resulted in fractionation of the noble gas abundance, as discussed in the following section.

\section{RESULTS AND EVALUATION OF DATA QUALITY}

Several chemical parameters were measured in the samples recovered in the titanium coil, as described in Behrmann, Lewis, Musgrave, et al. (1992). Results of these analyses are summarized in Table 1. The data obtained for noble gas abundances in the pore fluid recovered in the copper-coils are listed in Table 2 . Several sampling and analytical factors may have resulted in deviations of the noble gas abundance measured from the actual pore-fluid composition. A summary of the possible processes that can alter the gas content of the sampled pore fluids, as well as the expected resulting biases are presented in Table 3 .

The chloride composition of the in-situ fluids (Table 1) is plotted versus depth on Figure 5; this figure also includes data for the chlorinity of the pore fluids obtained by squeezing sediment samples. A discussion on the geochemical processes leading to the anomalies in the chloride distributions is presented in Behrmann, Lewis, Musgrave, et al. (1992); here it suffices to use these distributions as indicators of the consistency between data obtained with the WSTP with those obtained by squeezing. WSTP results for Site 859 show good agreement with the data obtained by squeezing. Deployment of the tool in a fractured formation at Sites 860 and 861 may have resulted in contamination of the in-situ samples with surface seawater used as drilling fluid (Case 1, Table 3); this contamination is reflected in the differences in the chloride contents of the WSTP and squeezed samples. Possible addition of surface seawater to the WSTP samples will result in a lower absolute value for the helium concentration, and a shift of the ${ }^{3} \mathrm{He} /{ }^{4} \mathrm{He}$ to the air ratio. Such a bias may have affected the distributions of samples from Cores 141-860B-5H (E) and 17X (I) as indicated by the deviations in the chloride values (Fig. 5).

In the first two deployments at Site 863, the chloride values of the fluid in the titanium coil shows very good agreement with those obtained from the squeezed cakes. The subsequent three WSTP deployments correspond to a zone of very poor core recovery, and therefore comparison with data from squeeze cakes can not be made. In-situ temperature data collected at Site 863 indicate that the tool penetrated the formation, and except for the sample from Core $863 \mathrm{~A}$ $7 \mathrm{X}$ (for which the temperature data is not of the highest quality) there seems to be no thermal evidence for drill fluid contamination (Brown et al., this volume).

Noble gas concentrations (Table 2) normalized to air-saturated seawater (ASSW) are illustrated in Figure 6. The concentration of neon in all the samples is similar to or higher than its saturation value, whereas in some of the samples the heavier rare gases are undersaturated. Undersaturation values may be due to contamination with the degassed water present in the WSTP tool prior to sampling (Case 2, Table 3). However, in all cases the volume collected in the overflow chamber (see Table 1) is larger than that contained within the sampler $(50 \mathrm{ml})$, and thus we may assume that all the degassed water was displaced. Values lower than ASSW may also indicate that the gas extraction was not performed quantitatively (Case 5, Table 3). In this case some fractionation in the absolute abundance is likely to occur, and consequently the heavier rare gases may be depleted relative to helium and neon; but the elementary isotopic ratios should not be significantly affected.

The majority of measured noble gas concentrations, however, are higher than the air-saturated seawater values (Fig. 6). In all instances the samples were collected by displacing degassed water in the WSTP tool, and therefore the possibility that the supersaturations are due to contamination by air bubbles trapped in the sampling device is small (Case 4, Table 3). Furthermore, any significant post-sampling contamination with ambient seawater is unlikely. There is, however, evidence for the formation of methane bubbles inside the sampler resulting from the extremely high levels of methane in these sediments (Table 1). As soon as the partial pressure of methane in the 

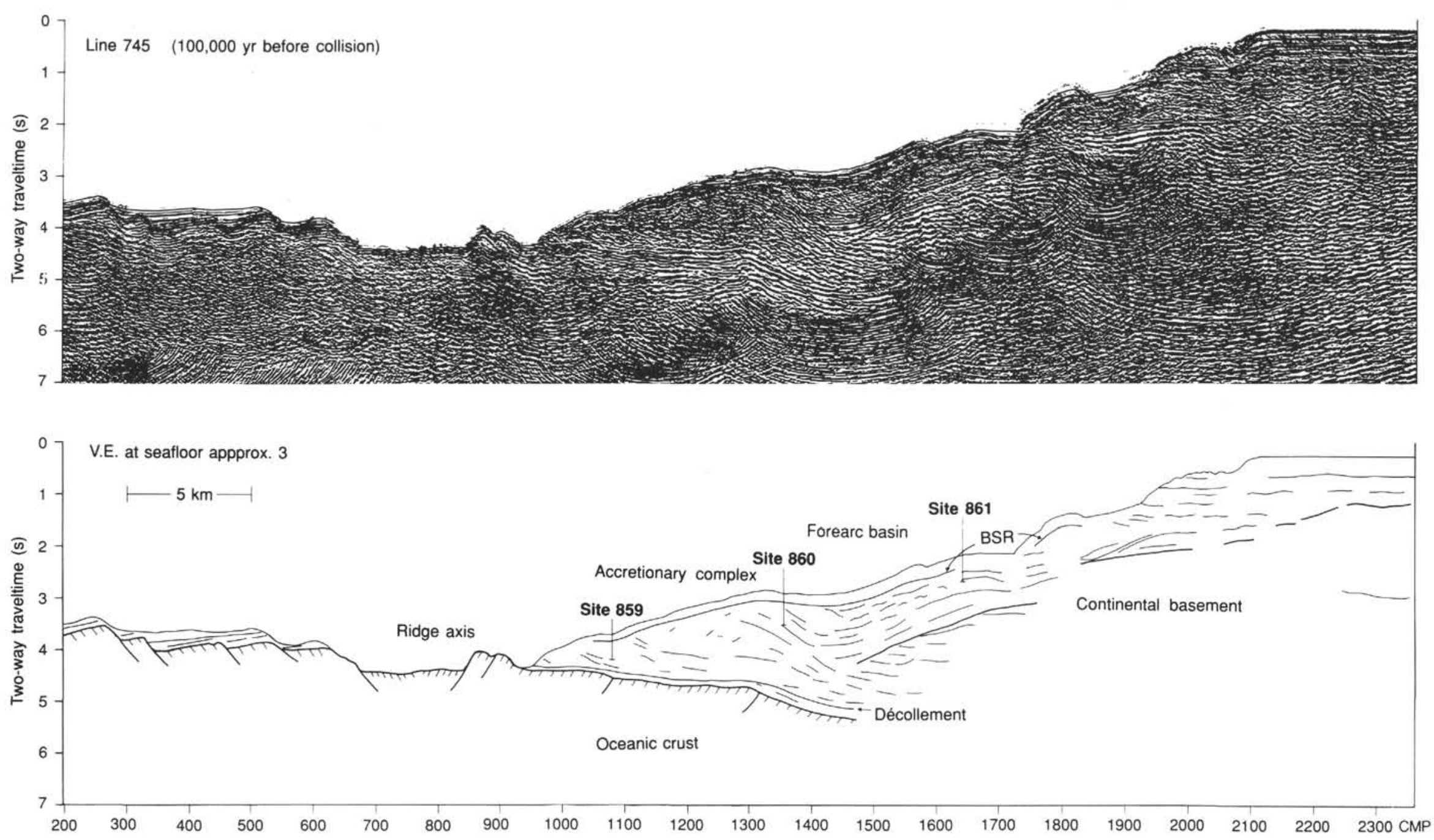

Figure 2. Seismic Line 745 and a line drawing interpretation depicting the position of Sites 859,860 , and 861 . This transect lies $18 \mathrm{~km}$ north of the present day Chile Triple Junction (for location see Fig. 1) and illustrates the margin characteristics just prior to ridge collision; with the axis of the subducting ridge lying just seaward of the trench. A bottom simulating reflector (BSR) was thought to demark the lower boundary of the gas hydrate stability within the accretionary wedge. From Behrmann, Lewis, Musgrave, et al., 1992. 


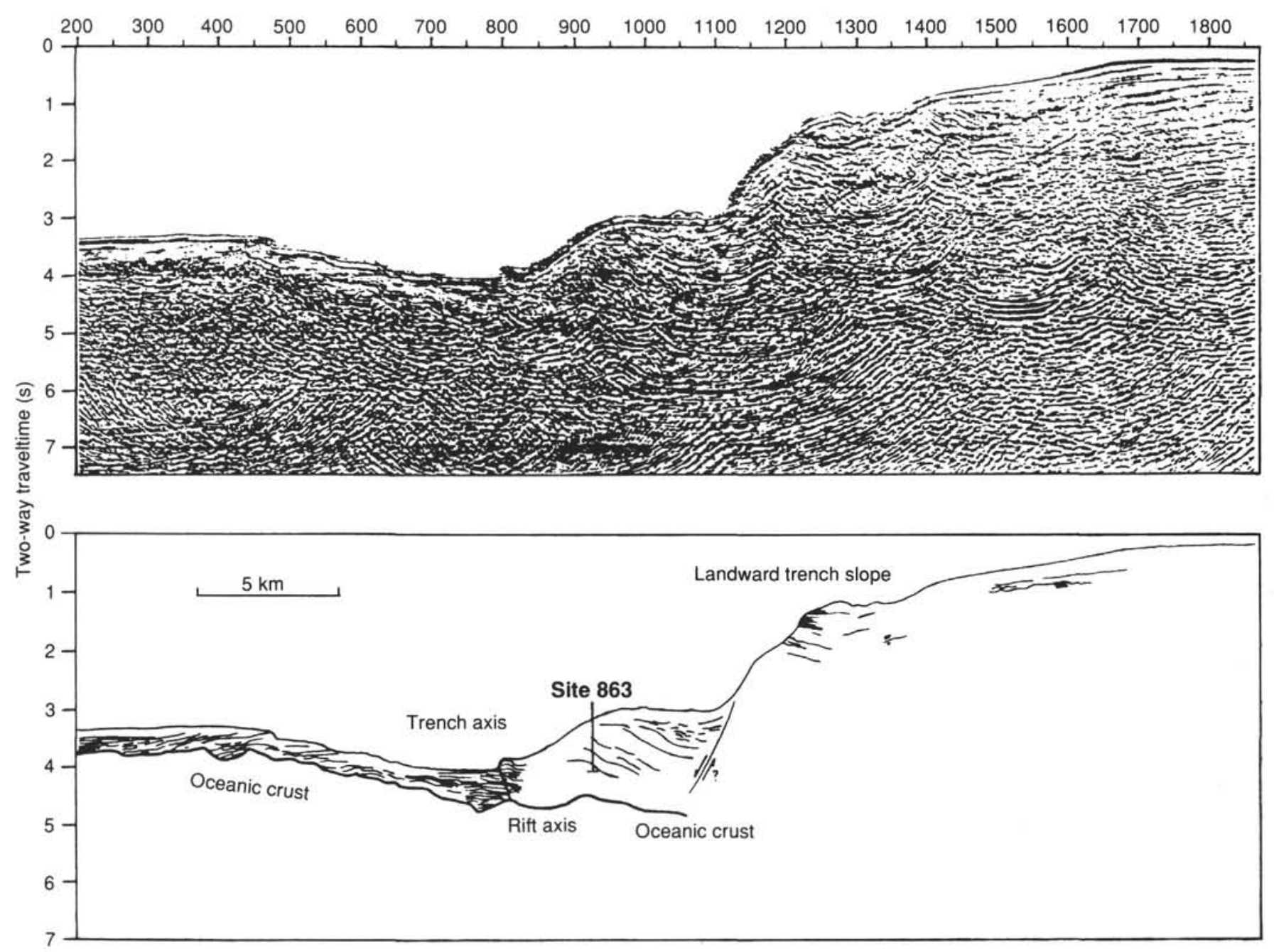

Figure 3. Seismic Line 751 and line drawing interpretation. It shows the location of Site 863 in the toe region of the accretionary wedge overriding the axial zone of the Chile Ridge. At this location the Chile Ridge was subducted within the last 50 k.y. From Behrmann, Lewis, Musgrave, et al., 1992.

Table 1. Composition of the fluids recovered in the titanium coil of the WSTP.

\begin{tabular}{ccccccccccc}
\hline Core & $\begin{array}{c}\text { Depth } \\
(\mathrm{mbsf})\end{array}$ & $\begin{array}{c}\mathrm{Vol} . \\
(\mathrm{ml})\end{array}$ & $\begin{array}{c}\mathrm{Sal} . \\
(\text { Refr })\end{array}$ & $\begin{array}{c}\mathrm{Cl} \\
(\mathrm{mM})\end{array}$ & $\begin{array}{c}\mathrm{SO}_{4} \\
(\mathrm{mM})\end{array}$ & $\begin{array}{c}\mathrm{Mg} \\
(\mathrm{mM})\end{array}$ & $\begin{array}{c}\mathrm{Ca} \\
(\mathrm{mM})\end{array}$ & $\begin{array}{c}\mathrm{CH}_{4} \\
(\mathrm{ppm})\end{array}$ & $\begin{array}{c}\mathrm{C}_{2} \mathrm{H}_{6} \\
(\mathrm{ppm})\end{array}$ & $\begin{array}{c}\text { Vol. OF } \\
(\mathrm{ml})\end{array}$ \\
\hline $859 \mathrm{~A}-$ & & & & & & & & & & \\
$8 \mathrm{X}$ & 49.0 & 6.0 & 33.5 & 406.0 & 0.4 & 22.1 & 5.3 & $\mathrm{NA}$ & $\mathrm{NA}$ & 153 \\
$11 \mathrm{X}$ & 68.3 & 6.0 & 35.0 & 609.0 & 1.1 & 21.6 & 6.0 & $\mathrm{NA}$ & $\mathrm{NA}$ & 600 \\
$860 \mathrm{~B}-$ & & & & & & & & & & \\
$5 \mathrm{H}$ & 29.9 & 6.0 & 32.0 & 519.0 & 26.7 & 50.7 & 9.7 & $1.60 \mathrm{E}+02$ & $\mathrm{ND}$ & 1200 \\
$10 \mathrm{X}$ & 68.7 & 6.0 & 31.0 & 522.0 & 26.9 & 50.9 & 9.2 & $4.90 \mathrm{E}+03$ & $\mathrm{ND}$ & 235 \\
$14 \mathrm{X}$ & 99.1 & 6.0 & 33.0 & 517.0 & 25.2 & 45.0 & 8.4 & $5.70 \mathrm{E}+03$ & $\mathrm{ND}$ & 90 \\
$17 \mathrm{X}$ & 126.5 & 6.0 & 35.0 & 519.0 & 25.5 & 50.1 & 9.2 & $2.60 \mathrm{E}+01$ & $\mathrm{ND}$ & 310 \\
$861 \mathrm{C}-$ & & & & & & & & & & \\
$7 \mathrm{H}$ & 50.5 & 3.5 & 35.0 & 579.0 & 0.9 & 58.0 & 3.8 & $7.70 \mathrm{E}+05$ & 8.6 & 62 \\
$12 \mathrm{X}$ & 90.0 & 4.0 & 31.5 & 548.0 & 11.8 & 52.8 & 5.4 & $6.40 \mathrm{E}+05$ & 30 & 98 \\
$15 \mathrm{X}$ & 119.0 & 5.0 & 32.0 & 533.0 & 16.5 & 52.8 & 6.0 & $1.70 \mathrm{E}+05$ & 13.1 & 83 \\
$863 \mathrm{~A}-$ & & & & & & & & & & \\
$4 \mathrm{H}$ & 27.6 & 6.0 & 33.0 & 551.0 & 28.3 & 52.8 & 10.5 & $5.60 \mathrm{E}+02$ & $\mathrm{ND}$ & 400 \\
$7 \mathrm{X}$ & 56.1 & 7.5 & 34.0 & 555.0 & 26.5 & 52.5 & 10.3 & $\mathrm{NA}$ & $\mathrm{NA}$ & 80 \\
$10 \mathrm{X}$ & 85.1 & 5.5 & 34.0 & 539.0 & 25.7 & 50.5 & 9.0 & $2.90 \mathrm{E}+05$ & 485 & 850 \\
$13 \mathrm{X}$ & 114.0 & 7.0 & 33.0 & 536.0 & 26.9 & 50.7 & 10.1 & $2.80 \mathrm{E}+04$ & 13.9 & 860 \\
$16 \mathrm{X}$ & 143.0 & 6.0 & 33.0 & 538.0 & 27.8 & 51.5 & 10.0 & $6.20 \mathrm{E}+02$ & $\mathrm{ND}$ & 1100 \\
\hline
\end{tabular}

Notes: $\mathrm{NA}=$ not available, $\mathrm{ND}=$ not detected. Data from Behrmann, Lewis, Musgrave, et al., 1992. Volume recovered in the overflow chamber (Vol. OF) is included as an indication of the tool performance (see text). 
Table 2. Noble gas abundance (type MM-1200 mass spectrometer) and 3He/4He ratios (MM-3000 spectrometer) for samples recovered in copper coils of the WSTP tool.

\begin{tabular}{|c|c|c|c|c|c|c|c|c|c|c|}
\hline Core & $\begin{array}{l}\text { Depth } \\
\text { (mbsf) }\end{array}$ & $\begin{array}{l}\text { Sample } \\
\text { ID }\end{array}$ & $\begin{array}{l}\text { Weight } \\
\text { (g) }\end{array}$ & $\begin{array}{c}\text { He E-7 } \\
\text { MM } 1200\end{array}$ & $\begin{array}{c}\text { Ne E-7 } \\
\text { MM1200 }\end{array}$ & $\begin{array}{c}\text { Ar E-4 } \\
M M 1200\end{array}$ & $\begin{array}{c}\text { KrE-8 } \\
M M 1200\end{array}$ & $\begin{array}{c}\text { Xe E-8 } \\
\text { MM1200 }\end{array}$ & $\begin{array}{c}3 \mathrm{He} / 4 \mathrm{He} \mathrm{E}-6 \\
\mathrm{MM} 3000\end{array}$ & $\begin{array}{l}\mathrm{He} / \mathrm{Ne} \text { E-1 } \\
\mathrm{MM} 3000\end{array}$ \\
\hline $\begin{array}{l}859 \mathrm{~A}- \\
8 \mathrm{X}\end{array}$ & 49.0 & G & 9 & 16.76 & 3.06 & 6.39 & 11.33 & 0.7 & 0.48 & 53 \\
\hline $\begin{array}{c}860 \mathrm{~B}- \\
5 \mathrm{H} \\
14 \mathrm{X} \\
17 \mathrm{X}\end{array}$ & $\begin{array}{r}29.9 \\
99.1 \\
126.5\end{array}$ & $\begin{array}{l}E \\
F \\
I\end{array}$ & $\begin{array}{l}40 \\
36 \\
40\end{array}$ & $\begin{array}{l}1.11 \\
6.99 \\
2.11\end{array}$ & $\begin{array}{l}1.83 \\
8.92 \\
1.95\end{array}$ & $\begin{array}{l}3.04 \\
6.39 \\
2.95\end{array}$ & $\begin{array}{c}7.01 \\
10.9 \\
6.88\end{array}$ & $\begin{array}{l}0.93 \\
1.23 \\
0.99\end{array}$ & $\begin{array}{l}0.61 \\
0.55 \\
\text { NA }\end{array}$ & $\begin{array}{l}5.6 \\
7.9 \\
\text { NA }\end{array}$ \\
\hline $\begin{array}{l}861 \mathrm{C}- \\
12 \mathrm{X}\end{array}$ & 90.0 & $\mathrm{H}$ & 22 & 42.15 & 5.67 & 5.54 & 11.73 & 1.57 & 0.14 & 69.9 \\
\hline $\begin{array}{c}863 \mathrm{~A}- \\
4 \mathrm{H} \\
7 \mathrm{X} \\
10 \mathrm{X} \\
16 \mathrm{X}\end{array}$ & $\begin{array}{r}27.6 \\
56.1 \\
85.1 \\
143.0\end{array}$ & $\begin{array}{l}\text { D } \\
\text { B } \\
\text { A } \\
\text { C }\end{array}$ & $\begin{array}{l}37 \\
37 \\
28 \\
38\end{array}$ & $\begin{array}{l}\text { NA } \\
2.26 \\
3.33 \\
1.23\end{array}$ & $\begin{array}{l}\text { NA } \\
6.2 \\
7.17 \\
4.16\end{array}$ & $\begin{array}{l}\text { NA } \\
5.47 \\
6.53 \\
2.27\end{array}$ & $\begin{array}{c}\text { NA } \\
10.5 \\
14.2 \\
7.73\end{array}$ & $\begin{array}{l}\text { NA } \\
1.3 \\
2.1 \\
1.08\end{array}$ & $\begin{array}{l}0.68 \\
1.43 \\
1.55 \\
1.22\end{array}$ & $\begin{array}{l}6.7 \\
3.6 \\
4.5 \\
3.4\end{array}$ \\
\hline ASSW & $m p=1$. & C. $\mathrm{sal}=$ ? & $4.65 \mathrm{ppt})$ & 0.39 & 1.74 & 3.70 & 9.11 & 1.29 & 1.36 & 2.23 \\
\hline
\end{tabular}

Notes: $\mathrm{NA}=$ not available. $\mathrm{ASSW}=$ air-saturated seawater. Equilibrium concentrations were calculated following Weiss (1971). Benson and Krause (1980), and Ozima and Podoseck (1983). Data for the He/Ne ratios obtained with the MM-3000 are included for comparison. The concentrations are given in volume of gas $\left(\mathrm{cm}^{3}\right)$ at standard temperature and pressure (STP) per gram.

Table 3. Sampling and analytical processes which may alter the gas content of the sampled pore fluids and expected bias in the results.

\begin{tabular}{|c|c|}
\hline Potential problem & Resulting bias \\
\hline $\begin{array}{l}\text { 1. Contamination with drilling } \\
\text { fluid (surface seawater). }\end{array}$ & $\begin{array}{l}\text { Dilution of any terrigenic signal: Lower }{ }^{4} \mathrm{He} \\
\text { concentration. }{ }^{3} \mathrm{He} /{ }^{4} \mathrm{He} \text { shifted to } \mathrm{R}_{\text {air }}\end{array}$ \\
\hline $\begin{array}{l}\text { 2. Contamination with degassed } \\
\text { water in the WSTP tool. }\end{array}$ & $\begin{array}{l}\text { Lower gas concentrations, gas ratios remain } \\
\text { unchanged. }\end{array}$ \\
\hline $\begin{array}{l}\text { 3. Formation of gas bubbles } \\
\text { inside the WSTP tool. }\end{array}$ & $\begin{array}{l}\text { Gas fractionation: light gases are enriched in } \mathrm{CH}_{4} \\
\text { bubbles. }\end{array}$ \\
\hline 4. Atmospheric contamination. & $\begin{array}{l}\text { Higher absolute gas concentrations, }{ }^{4} \mathrm{He} / \mathrm{Ne} \text { and } \\
{ }^{3} \mathrm{He} /{ }^{4} \mathrm{He} \text { shifted to air values. }\end{array}$ \\
\hline 5. Non-quantitative extraction. & $\begin{array}{l}\text { Lower absolute concentrations. Fractionation in } \\
\text { absolute gas abundance may occur, gas ratios } \\
\text { probably remain unchanged. }\end{array}$ \\
\hline
\end{tabular}

water exceeds the pressure of the sample container, methane bubbles will form inside the sampling line. These bubbles are initially free of rare gases, and thus they will strip gases from the surrounding pore fluid. Due to their progressively increasing solubilities and decreasing diffusion constants, $\mathrm{He}, \mathrm{Ne}, \mathrm{Ar}, \mathrm{Kr}$, and $\mathrm{Xe}$, will be fractionated, with the light rare gases being enriched in the $\mathrm{CH}_{4}$-bubbles relative to the heavier ones (Case 3, Table 3). The data presented in Figure 6 show decreasing supersaturation with increasing element number, an observation that suggests that our samples are dominated by trapped gas bubbles. If the bubbles are sampled preferentially relative to the gas-depleted fluid, the neon concentration may be depleted relative to helium. Nevertheless, since the solubility and diffusion constants for helium and neon are similar; we have assumed no significant effect on the $\mathrm{He} / \mathrm{Ne}$ ratio, and have used the atmospheric $\mathrm{He} / \mathrm{Ne}$ value as a zero-order correction in our calculations (Equation 1 in the discussion). Using the same arguments, we can justify a minimal effect of bubble formation on the ${ }^{3} \mathrm{He} /{ }^{4} \mathrm{He}$ ratios.

\section{DISCUSSION}

Changes in the ${ }^{3} \mathrm{He} /{ }^{4} \mathrm{He}$ ratio of the samples can be explained in terms of a mixture of atmospheric helium with radiogenic and mantle components (Sano and Wakita, 1985). The variation in the values of these parameters in the samples from the Chile Triple Junction are shown in Figure 7. The majority of the samples fall on the mixing line between air-saturated water and radiogenic helium. Only two samples from Site 863 indicate presence of mantle helium. This observation is consistent with the fact that Site 863 was drilled directly above the

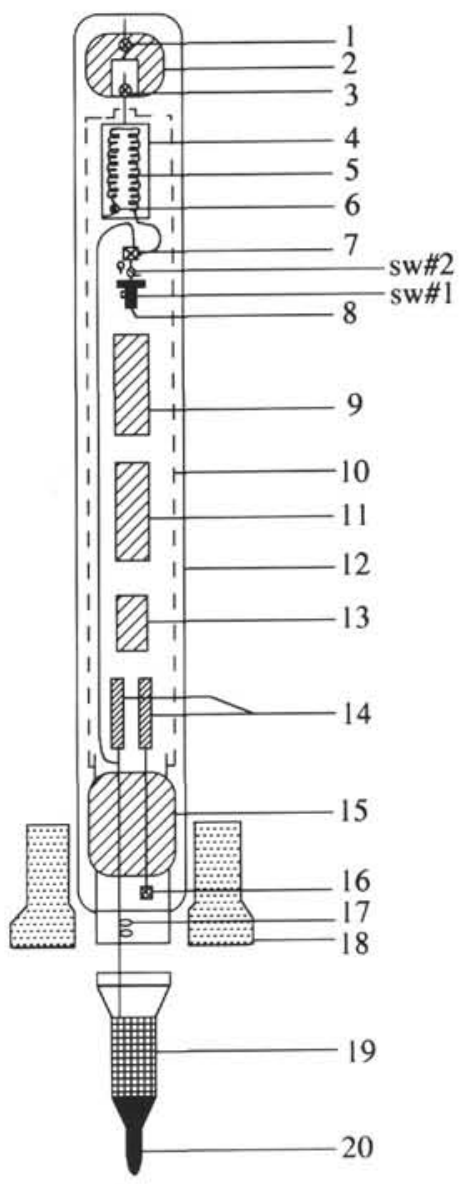

Figure 4. Block diagram (not to scale) of the WSTP tool. $1=$ pressure case relief valve, 2 = upper pressure case bulkhead, $3=$ sample chamber pressure relief valve, $4=$ sample overflow chamber, $5=$ titanium and copper sample coils, $6=$ sample coil pressure relief check valve, $7=$ sampling control valve, $8=$ D.C gear motor, $9=$ timer controller, $10=$ inner case assembly, $11=$ data recorder and other electronic packages, 12 = pressure case, $13=$ nickel-cadmium battery pack, 14 = pressure transducers, $15=$ lower pressure case bulkhead, $16=$ pressure transducer inlet filter, $17=$ pore fluid inlet tubing, 18 = drill bit, $19=$ filter element, 20 = thermistor probe, sw $\# 1$ = motor shut-off and reversing switch, and sw\#2 = manual motor switch. Solid heavy lines indicate fluid pathways. 

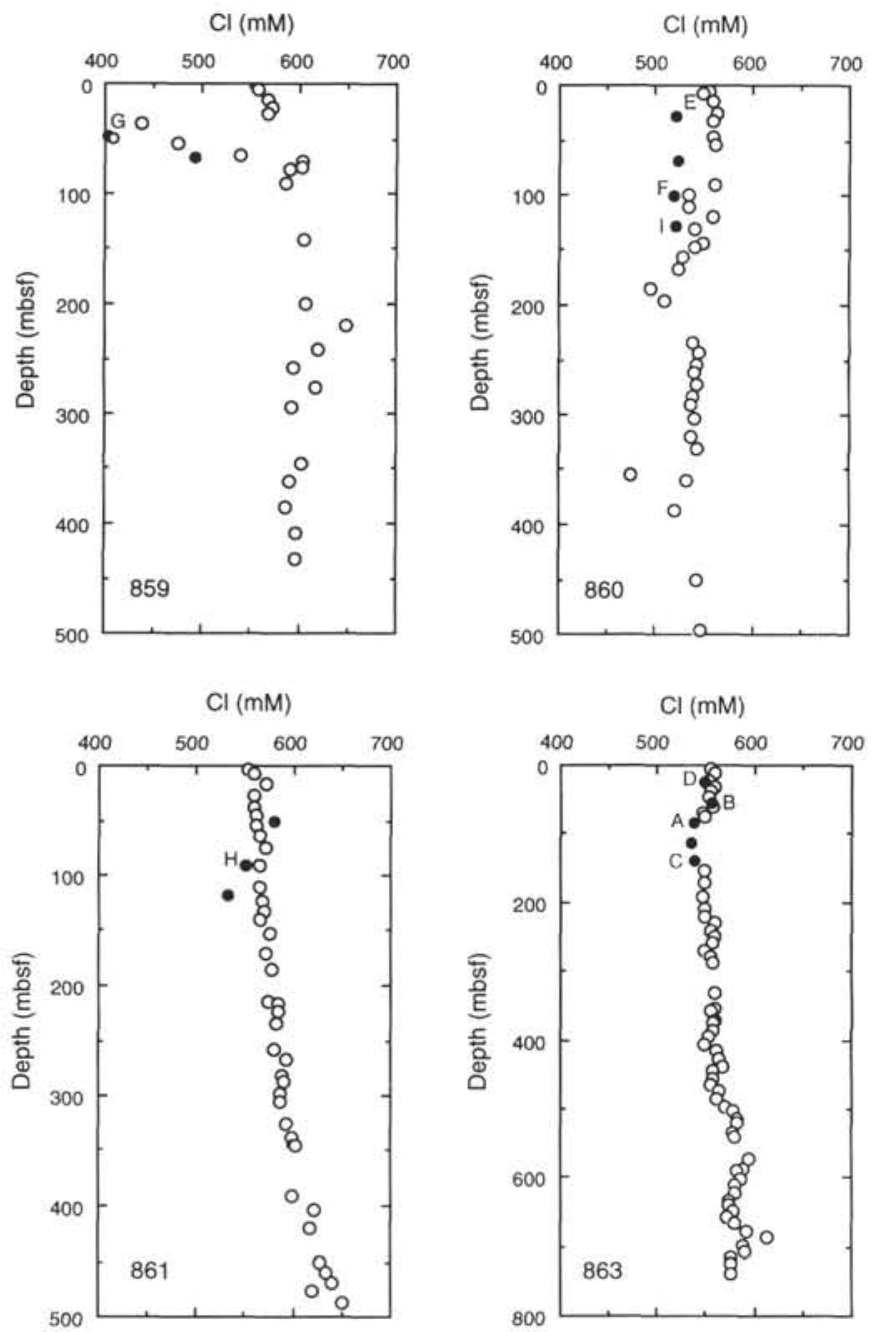

Figure 5. Chloride composition of pore fluids sampled during Leg 141. Open circles represent data obtained from squeezed whole rounds and closed circles indicate the chloride concentration in the WSTP samples (data from Behrmann, Lewis, Musgrave et al., 1992). Letters are used to designate the samples analyzed for noble gas composition as indicated in Table 2.

recently-subducted Chile ridge axis. Published ${ }^{3} \mathrm{He} /{ }^{4} \mathrm{He}$ and ${ }^{4} \mathrm{He} / \mathrm{Ne}$ ratios in drilled samples from the Japan Trench and the Nankai Trough are included in Figure 7. As expected from their geotectonic settings, none of these samples show a contribution of mantle helium.

We have assumed that the atmosphere is the only source of dissolved neon, and thus, we may use the neon excess $\left(\mathrm{Ne}_{\text {exc }}\right)$ relative to the solubility equilibrium value $\left(\mathrm{Ne}_{\mathrm{eq}}\right)$ to correct for the amount of atmospheric helium in the sample:

$$
\mathrm{Ne}_{\text {tot }}=\mathrm{Ne}_{\text {eq }}+\mathrm{Ne}_{\text {exc }}
$$

Using the atmospheric $\mathrm{He} / \mathrm{Ne}$ ratio of 0.288 , and assuming that additional helium supersaturations are only due to terrigenic sources or to tritium decay we obtain:

$$
{ }^{3} \mathrm{He}_{\text {tot }}={ }^{3} \mathrm{He}_{\text {eq }}+{ }^{3} \mathrm{He}_{\text {exc }}+{ }^{3} \mathrm{He}_{\text {terr }}+{ }^{3} \mathrm{He}_{\text {trit }} \text {, }
$$

and

$$
{ }^{4} \mathrm{He}_{\mathrm{tot}}={ }^{4} \mathrm{He}_{\mathrm{eq}}+{ }^{4} \mathrm{He}_{\mathrm{exc}}+{ }^{4} \mathrm{He}_{\mathrm{terr}} .
$$

Since the tritium content of the water at the sampling depth is very low, and the incubation time inside the copper coil was short, the
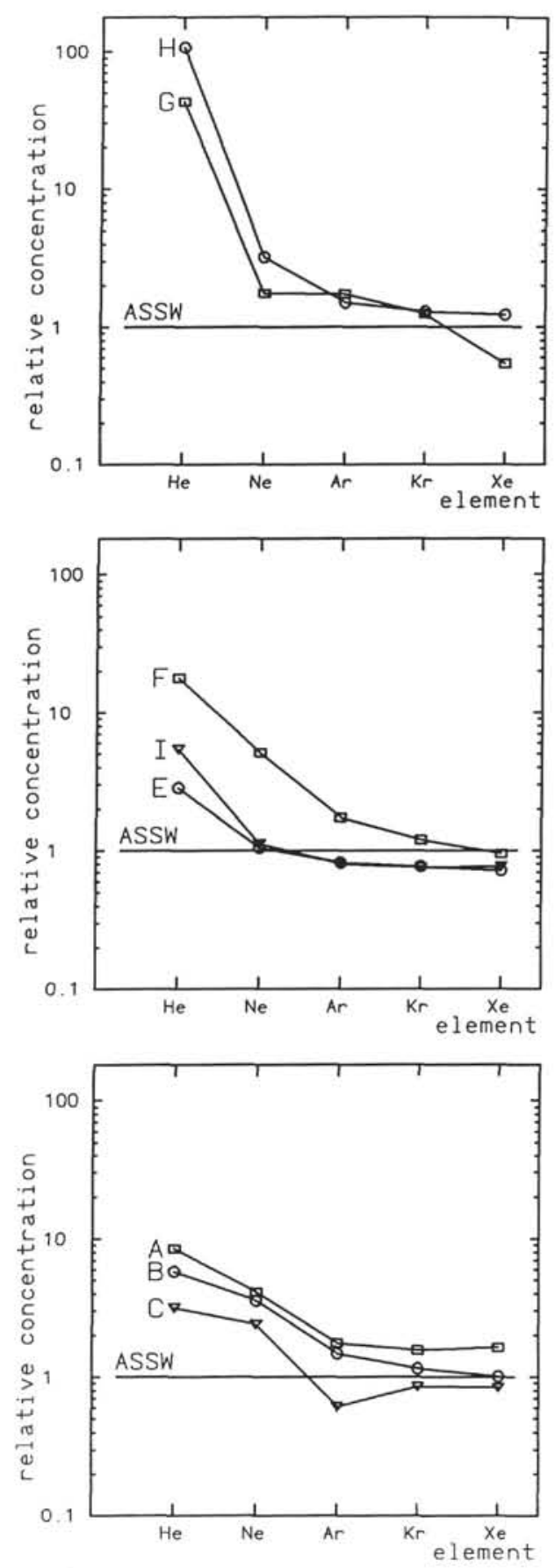

Figure 6. Noble gas concentrations for fluid samples obtained in situ with the WSTP, normalized to air-saturated seawater values (ASSW; $\mathrm{T}=1.8^{\circ} \mathrm{C}, \mathrm{S}=$ $34.65 \%$ ). The ASSW concentrations were calculated from Weiss (1971) and Ozima and Podosek (1983). Letters are used to designate the samples as indicated in Table 2.

amount of ${ }^{3} \mathrm{He}$ from tritium decay $\left({ }^{3} \mathrm{He}_{\text {trit }}\right)$ can be neglected. The terrigenic helium $\left(\mathrm{He}_{\mathrm{ter}}\right)$ has two components: a radiogenic source $\left(\mathrm{He}_{\text {crust }}\right)$ derived from the sediments (crustal origin), and a juvenile or mantle fraction $\left(\mathrm{He}_{\text {mantle }}\right)$ :

$$
\mathrm{He}_{\text {terr }}=\mathrm{He}_{\text {crust }}+\mathrm{He}_{\text {mantle }} \text {. }
$$

This set of equations can be used to simulate the observed helium and neon compositions in terms of their components. The equilibrium concentrations are estimated using the solubility of these gases in 
Table 4. Partitioning of helium and neon in terms of a mixture of air-equilibrated seawater (eq), gas phase with atmospheric gas ratios (xs) and terrigenic (terr) components.

\begin{tabular}{|c|c|c|c|c|c|c|c|c|c|c|}
\hline \multirow[b]{2}{*}{ Hole, core } & \multirow[b]{2}{*}{ ID } & \multicolumn{2}{|c|}{$\mathrm{Ne} \times 10^{-7}$} & \multicolumn{3}{|c|}{${ }^{4} \mathrm{He} \times 10^{-7}$} & \multicolumn{3}{|c|}{${ }^{3} \mathrm{He} \times 10^{-13}$} & \multirow{2}{*}{$\frac{{ }^{3} \mathrm{He} /{ }^{4} \mathrm{He}}{\text { terr }}$} \\
\hline & & eq & xs & eq & xs & terr & eq & $\mathrm{xs}$ & terr & \\
\hline $860 \mathrm{~B}-5 \mathrm{H}$ & $\mathrm{E}$ & 1.74 & 0.09 & 0.39 & 0.03 & 0.69 & 0.53 & 0.04 & 0.10 & $0.11 * R_{\text {a }}$ \\
\hline $860 B-14 X$ & $\mathrm{~F}$ & 1.74 & 7.18 & 0.39 & 2.07 & 4.53 & 0.53 & 2.86 & 0.45 & $0.73 * R_{\text {air }}$ \\
\hline $861 C-12 X$ & $\mathrm{H}$ & 1.74 & 3.93 & 0.39 & 1.13 & 40.63 & 0.53 & 1.56 & 3.81 & $0.07^{*} R_{\text {iu }}$ \\
\hline $863 A-7 X$ & B & 1.74 & 4.46 & 0.39 & 1.28 & 0.59 & 0.53 & 1.77 & 0.93 & $1.14 * \mathrm{R}_{\mathrm{air}}$ \\
\hline $863 \mathrm{~A}-10 \mathrm{X}$ & A & 1.74 & 5.43 & 0.39 & 1.56 & 1.38 & 0.53 & 2.16 & 2.47 & $1.29 * R_{\text {air }}$ \\
\hline $863 A-16 X$ & C & 1.74 & 2.42 & 0.39 & 0.70 & 0.14 & 0.53 & 0.97 & 0.01 & $0.05^{*} \mathrm{R}_{\mathrm{air}}$ \\
\hline
\end{tabular}

Note: The terrigenic helium includes both radiogenic and primordial contributions. All the concentrations are given in units of gas volume $\left(\mathrm{cm}^{3}\right)$ at standard temperature and pressure (STP) per gram.

seawater with a salinity of 34.65 and a potential temperature of 1.8 ${ }^{\circ} \mathrm{C}$, based on the solubilities published by Weiss (1971) and Benson and Krause (1980). The values obtained for ${ }^{4} \mathrm{He}_{\mathrm{eq}},{ }^{3} \mathrm{He}_{\mathrm{eq}}$, and $\mathrm{Ne}_{\mathrm{eq}}$ are $3.94 \times 10^{-8}, 5.36 \times 10^{-14}$ and $1.74 \times 10^{-7} \mathrm{~cm}^{3} \mathrm{STP} / \mathrm{g}$ respectively. The helium generated by radioactive decay of $U$ and $T h$ within the Earth's crust is highly enriched in ${ }^{4} \mathrm{He}$; the ${ }^{3} \mathrm{He} /{ }^{4} \mathrm{He}$ ratio of this radiogenic component, relative to atmospheric values $\left(R / R_{A} ; R={ }^{3} \mathrm{He} /{ }^{4} \mathrm{He}, \mathrm{R}_{\mathrm{A}}=\right.$ $1.384 \times 10^{-6}$ ) has been shown to vary between 0.02 and 0.1 (Craig and Lupton, 1981). In contrast, mantle helium is characterized by ${ }^{3} \mathrm{He} /{ }^{4} \mathrm{He}$ ratios of approximately 5 to 30 times the atmospheric value. The highest values reflect an injection from the most undegassed (lower, undepleted) mantle (e.g., Loihi seamount $R / R_{A}=30$ ); whereas the hydrothermal MOR systems have shown a relatively uniform value for the $R / R_{A}$ equal to 8, suggesting an upper mantle of homogeneous composition (Lupton and Craig, 1981).

The results of the simulations using values for $R_{\text {crust }}$ and $R_{\text {mantle }}$ of $0.1 * R_{A}$ and $8 * R_{A}$, respectively, are listed in Tables 4 and 5 . It is important to note at this point that the helium excesses were reduced for an atmospheric component using the neon concentration and the $\mathrm{He} / \mathrm{Ne}$ ratio of air, as indicated by Equation 1. However, since we observe supersaturations in both helium and neon (Fig. 6), the $\mathrm{CH}_{4^{-}}$ bubble effect previously described is likely to have caused some bias in the data. Specifically, as neon in fact may be depleted by some degree relative to helium, we may have underestimated the "air component" in the bubbles, which means that the final ${ }^{4} \mathrm{He} / \mathrm{Ne}$ values may be a bit too high. Consequently, the estimated primordial fraction would be somewhat higher if it was possible to quantitatively correct for this effect.

The data for the sample from Core $859 \mathrm{~A}-8 \mathrm{X}(\mathrm{G})$ could not be simulated within the constraints of the model. It is likely that the extremely high gas content of this sample (only $9 \mathrm{~g}$ of fluid were present in the $40 \mathrm{~cm}^{3} \mathrm{Cu}$-sampler coil, Table 2) may have resulted in large errors during sampling and analysis. The data obtained for Sites 860 and 861 could be simulated using a mixture of atmospheric and radiogenic helium-components. A mantle-helium signal is only present in two samples from Site 863. Unfortunately, we have no absolute values for the helium concentration of the sample from Core $863 \mathrm{~A}-4 \mathrm{H}$ (D). However, Figure 7 indicates that this sample has a higher radiogenic component than that from Core 863A-16X (C), which suggests no mantle component in this sample. Fractions of mantle-helium in the upper $300 \mathrm{~m}$ at this site are presented as a function of depth in Figure 8 . Drilling from 75 and $150 \mathrm{~m}$ had very poor core recovery. It is assumed that this section corresponds to a tectonic discontinuity because of the abrupt change in structural style and a likely age inversion between early Pleistocene in Cores $863 \mathrm{~A}-1 \mathrm{H}$ and $863 \mathrm{~A}-2 \mathrm{H}$ and late Pleistocene in Core $863 \mathrm{~A}-8 \mathrm{X}$. This interval also corresponds to a zone of high porosity and to a temperature anomaly, which suggests lateral advection of fluids (Behrmann, Lewis, Musgrave, et al., 1992).

Results of chemical analyses of squeeze cakes in the upper $300 \mathrm{~m}$ at Site 863 are also shown in Figure 8. These distributions illustrate a discontinuity in the depth profiles that may indicate lateral fluid flow. The dissolved components show a depletion in the concentration of $\mathrm{Mg}, \mathrm{Sr}, \mathrm{K}$, and $\mathrm{SO}_{4}$; observations that are consistent with experimen-

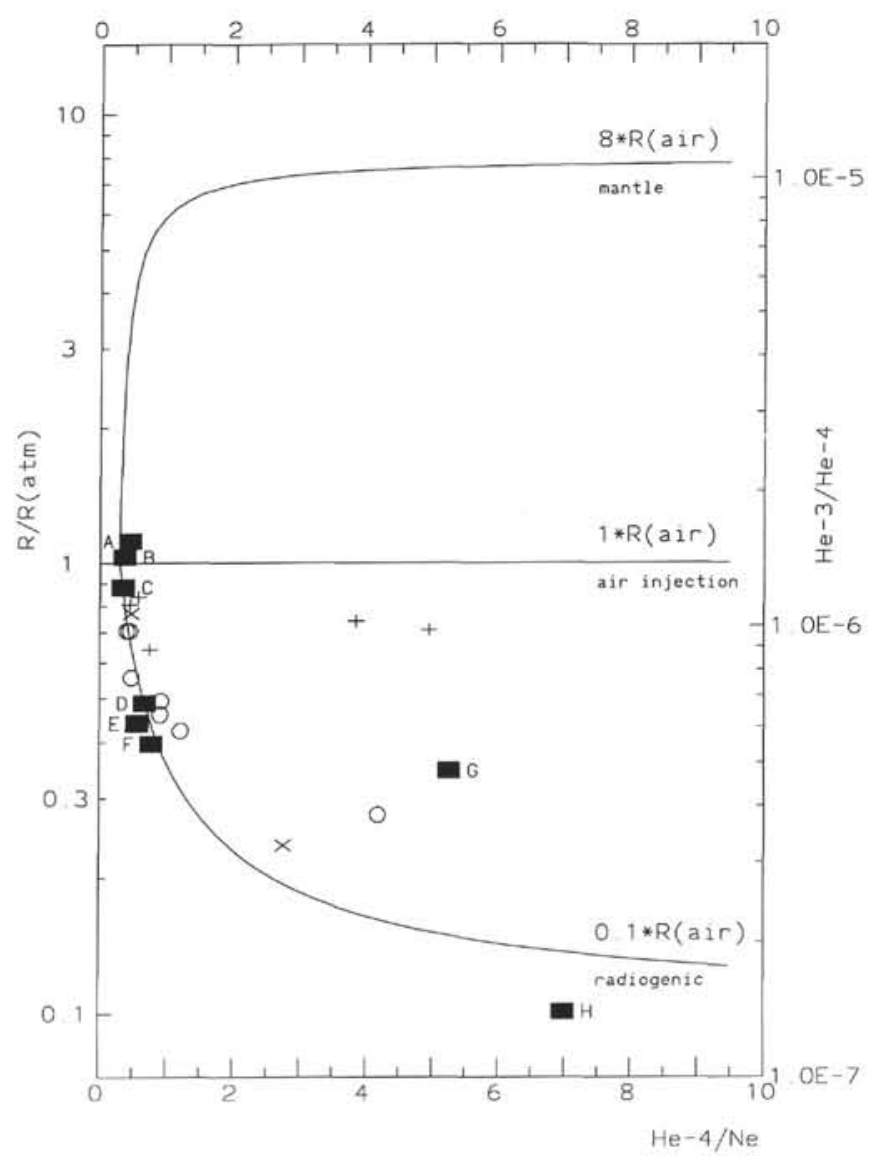

Figure 7. Relationship between the ${ }^{3} \mathrm{He} /{ }^{4} \mathrm{He}$ and the $\mathrm{He} / \mathrm{Ne}$ ratios in pore water samples (obtained with the MM- 3000 mass spectrometer). The curves indicate mixing between air-saturated seawater, mantle and crustal components; using a value for $\mathrm{R}_{\mathrm{A}}=1.384 \times 10^{-6}$. Data from the Chile Triple Junction are shown by squares and are designated by letters that correspond to the samples indicated in Table 2. Data from ODP Site 583 in the Nankai Trough (circles, from Sano and Wakita, 1985), Site 584 in the Japan Trench (crosses, Sano and Wakita, 1985) and from the Japan Sea (+ signs, Sano et al., 1992) are included for comparison. The data for the sample from Core $859 \mathrm{~A}-8 \mathrm{X}(\mathrm{G})$ is very uncertain; the high gas content of this sample resulted in large errors during sampling and analysis (see text).

tal basalt-seawater simulations and with measured compositions of hydrothermal fluids (Mottl and Holland, 1978; Edmond et al., 1982). However, these chemical data alone cannot rule out the possibility of an in-situ diagenetic effect. Alteration of volcanogenic material present in these sequences may result in a diagenetic front characterized by chemical discontinuities similar to those depicted in Figure 8 (Zheng et al., this volume). The helium data, on the other hand, shows 


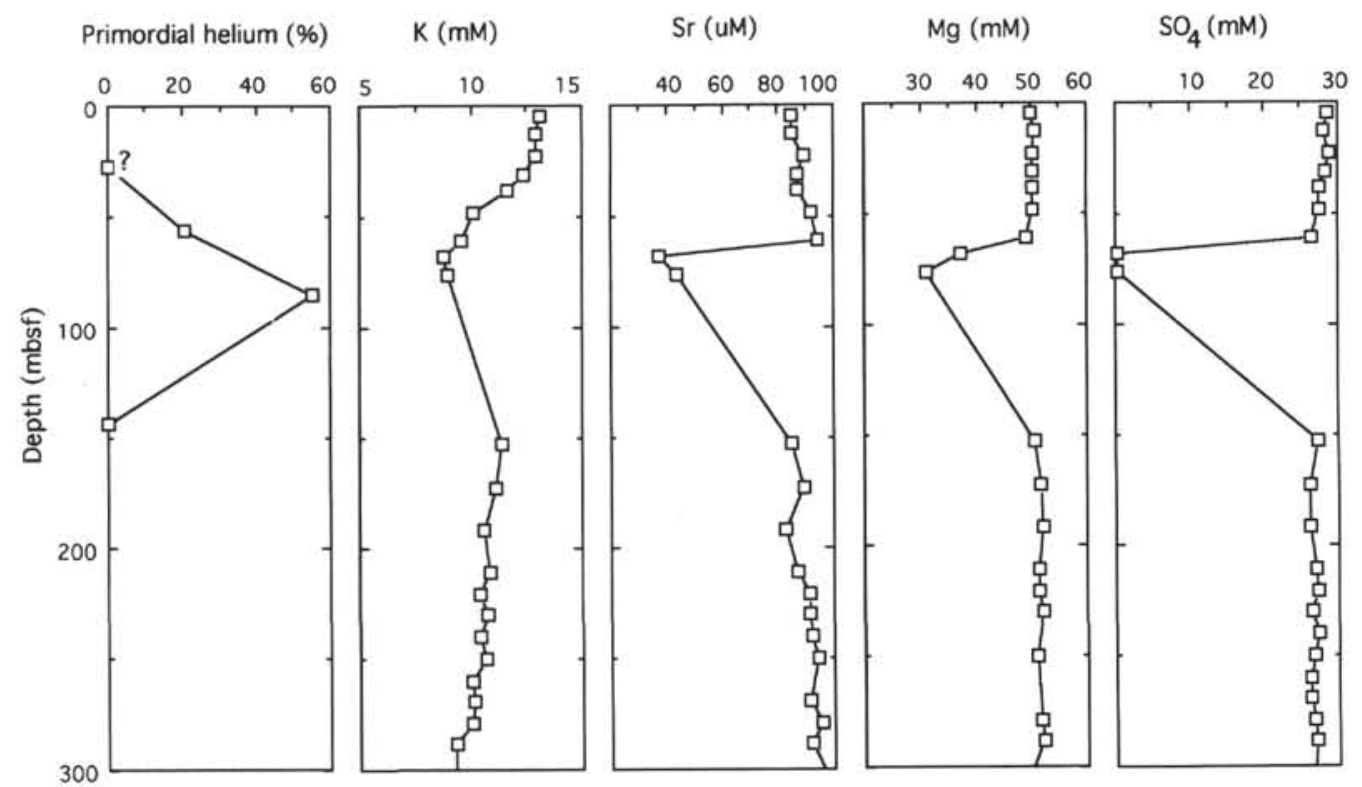

Figure 8. Depth profiles for primordial helium, potassium, sulfate, magnesium and strontium in the upper $300 \mathrm{mbsf}$ of Site 863 . For all the samples except from $863 \mathrm{~A}-4 \mathrm{H}$, the primordial helium component was calculated using $\left(\mathrm{R}_{\mathrm{R}} \mathrm{R}_{\mathrm{A}}\right)_{\text {crust }}=0.1,\left(\mathrm{R} / \mathrm{R}_{\mathrm{A}}\right)_{\text {mantle }}=8$, and $\mathrm{R}_{\mathrm{A}}=1.384 \times 10^{-6}$ (Tables 4 and 5 ); a negligible contribution for the primordial component in the sample from Core $863 \mathrm{~A}-4 \mathrm{H}$ (denoted with "?") was inferred from the He/ $\mathrm{Ne}$ and ${ }^{3} \mathrm{He} /{ }^{4} \mathrm{He}$ ratios since there is no absolute concentration data for this sample (see text for discussion). The discontinuity in the chemical profiles at about 60 mbsf corresponds to an abrupt change in structural style, high porosity and a temperature anomaly indicative of lateral fluid advection. The enrichment in the primordial helium component in this horizon points to a hydrothermal source for the advecting fluid, a conclusion that is consistent with the fact that this site was drilled directly above the recently subducted Chile ridge axis.

Table 5. Partitioning of the terrigenic helium into radiogenic and primordial fractions.

\begin{tabular}{lrrrcc}
\hline & & & & \multicolumn{2}{c}{${ }^{3} \mathrm{He} /{ }^{4} \mathrm{He}$ E-6 } \\
\cline { 5 - 6 } Hole. core & ID & $\begin{array}{c}\text { Radiogenic } \\
(\%)\end{array}$ & $\begin{array}{c}\text { Primordial } \\
(\%)\end{array}$ & Modeled & Measured \\
\hline $860 \mathrm{~B}-5 \mathrm{H}$ & $\mathrm{E}$ & 175 & 0 & 0.60 & 0.61 \\
$860 \mathrm{~B}-14 \mathrm{X}$ & $\mathrm{F}$ & 1.150 & 0 & 0.58 & 0.55 \\
$861 \mathrm{C}-12 \mathrm{X}$ & $\mathrm{H}$ & 10.300 & 0 & 0.18 & 0.14 \\
$863 \mathrm{~A}-7 \mathrm{X}$ & $\mathrm{B}$ & 130 & 20 & 1.42 & 1.43 \\
$863 \mathrm{~A}-10 \mathrm{X}$ & $\mathrm{A}$ & 295 & 55 & 1.55 & 1.55 \\
$863 \mathrm{~A}-16 \mathrm{X}$ & $\mathrm{C}$ & 36 & 0 & 1.23 & 1.22 \\
\hline
\end{tabular}

Note: We have assumed values of $0.1 \% R_{A}$ and $8 * R_{A}$ for radiogenic and primordial helium. respectively, where $R_{A}=1.384 \times 10^{-6}$. The radiogenic and primordial fractions are given as percent deviation from the equilibrium values. Values for the ${ }^{3} \mathrm{He} /$ ${ }^{4} \mathrm{He}$ ratios estimated by the model as well as the measured values are included to give an indication of how well the simulations fit the data.

a clear indication of a mantle-derived helium in the samples recovered from 56.1 and $85.1 \mathrm{mbsf}$. If we assume a value for the ${ }^{3} \mathrm{He} /{ }^{4} \mathrm{He}$ ratio of the mantle helium fraction to be 8 times the atmospheric value, the mantle component shows values as high as $53 \%$ relative to the helium equilibrium concentration (Table 5). The mantle signature is only present in the samples corresponding to the zone of tectonic discontinuity; the sample from Core $863 \mathrm{~A}-16 \mathrm{X}$, which lies below this zone (143 mbsf), shows no mantle-He contribution. Therefore, based on the information provided by the noble gas data, we are able to conclude that the anomalies in the pore fluid chemistry correspond to lateral migration of fluid from a hydrothermal source likely to be associated with the subducting ridge axis.

\section{ACKNOWLEDGMENTS}

The authors wish to thank Hans Rupp for the use of the program utilized in the simulation of the helium components. In addition, we acknowledge the scientific members and crew of ODP Leg 141 for their assistance; in particular we thank Chieh Peng for her con- scientious participation in the shipboard geochemical work and Ted Gustafson for his skillful assistance in the preparation, deployment, and modifications to the WSTP tool. We thank Peter Schlosser and an anonymous reviewer for thorough and constructive reviews. This research was supported by a grant from the Deutsche Forschungsgemeinschaft (DFG) to M.E. Torres.

\section{REFERENCES*}

Barnes, R.O., 1988. ODP in-situ fluid sampling and measurement: a new wireline tool. In Mascle, A., Moore, J.C., et al., Proc. ODP, Init. Repts., 110: College Station, TX (Ocean Drilling Program), 55-63.

Barnes, R.O., and Clarke, W.B., 1987. Fluid kinematics, fluid residence times, and rock degassing in oceanic crust determined from noble gas contents of Deep Sea Drilling Project pore waters. J. Geophys. Res., 92:1249112506.

Bayer, R., Schlosser, P., Bönisch, G., Rupp, H., Zaucker, F., and Zimmek, G., 1989. Performance and blank components of a mass spectrometric system for routine measurement of helium isotopes and tritium by the ${ }^{3} \mathrm{He}$ ingrowth method. Sitzungsber. Heidelb. Akad. Wiss. Math.-Naturwiss. Kl., 5:241-279.

Behrmann, J.H., Lewis, S.D., Musgrave, R.J., et al., 1992. Proc. ODP, Init. Repts., 141: College Station, TX (Ocean Drilling Program).

Benson, B.B., and Krause, D., Jr., 1980. Isotope fractionation of helium during solution: a probe for the liquid state. J. Solution Chem., 9:895-909.

Craig, H., and Lupton, J.E., 1981. Helium-3 and mantle volatiles in the ocean and the oceanic crust. In Emiliani, C. (Ed.), The Sea (Vol. 7): The Oceanic Lithosphere: New York (Wiley), 391-428.

Edmond, J.M., von Damm, K.L., McDuff, R.E., and Measures, C.I., 1982. Chemistry of hot springs on the East Pacific Rise and their effluent dispersal. Nature, 297:187-191.

Igarashi, G., Kodera, M., Ozima, M., Sano, Y., Wakita, H., and Boulègue, J., 1987. Noble gas elemental and isotopic abundances in deep-sea trenches in the western Pacific. Earth Planet. Sci. Lett., 86:77-84.

\footnotetext{
Abbreviations for names of organizations and publications in ODP reference lists follow the style given in Chemical Abstracts Service Source Index (published by American
} Chemical Society), 
Lupton, J.E., 1983. Terrestrial inert gases: isotope tracer studies and clues to primordial components in the mantle. Annu. Rev. Earth Planet. Sci., $11: 371-414$.

Lupton, J.E., and Craig, H., 1981. A major helium-3 source at $15^{\circ} \mathrm{S}$ on the East Pacific Rise. Science, 214:13-18.

Mottl, M.J., and Holland, H.D., 1978. Chemical exchange during hydrothermal alteration of basalt by seawater. I. Experimental results for major and minor components of seawater. Geochim. Cosmochim. Acta, 42:1103-1115.

Ozima, M., and Podosek, F.A., 1983. Noble Gas Geochemistry: Cambridge (Cambridge Univ. Press).

Rudolph, J., Rath, H.K., and Sonntag, C., 1984. Noble gases and stable isotopes in ${ }^{14} \mathrm{C}$-dated palaeowaters from central Europe and the Sahara. In Isotope Geology: Vienna (IAEA), 467-477.

Sano, Y., Sakamoto, M., Ishibashi, J., Wakita, H., and Matsumoto, R., 1992. Helium isotope ratios of pore gases in deep-sea sediments, Leg 128, In
Pisciotto, K.A., Ingle, J.C., Jr., von Breymann, M.T., Barron, J., et al., Proc. ODP, Sci. Results, 127/128 (Pt. 1): College Station, TX (Ocean Drilling Program), 747-751.

Sano, Y., and Wakita, H., 1985. Geographical distribution of ${ }^{3} \mathrm{He} /{ }^{4} \mathrm{He}$ ratios in Japan: implications for arc tectonics and incipient magmatism. J. Geophys. Res., 90:8729-8741.

Weiss, R.F., 1971. Solubility of helium and neon in water and seawater. $J$. Chem. Eng. Data, 16:235-241.

Date of initial receipt: 19 August 1993

Date of acceptance: 8 March 1994

Ms 141SR-022 